\title{
Social control: knowledge and attitude of professionals in the Academia da Cidade Program
}

\author{
Controle social: conhecimento e atitude dos profissionais do Programa Academia \\ da Cidade
}

\section{AUTHOR'S \\ Cícero Adriano Melo Figueirêdo ${ }^{1,2}$ (D) \\ Bruno César Rodrigues da Silva ${ }^{1,2}$ (D) \\ Amanda Emmanuelly de Melo Tavares \\ Albuquerque $^{1,2}$ (i) \\ Mateus Gustavo Brainer ${ }^{1,2}$ (D) \\ Sulamita Emy Tavares de Oliveira Mendonça \\ Soares $^{1,2}$ (iD \\ Emmanuelly Correia de Lemos ${ }^{2,3}$ \\ 1 Programa Academia da Cidade. Secretaria \\ Municipal de Saúde do Recife, Recife, Pernambuco, \\ Brasil. \\ 2 Universidade de Pernambuco, Escola Superior de \\ Educação Física, Recife, Pernambuco, Brasil. \\ 3 Escola de Governo em Saúde Pública de \\ Pernambuco. Secretaria Estadual de Saúde de \\ Pernambuco, Recife, Pernambuco, Brasil}

\section{CORRESPONDING}

Cícero Adriano Melo Figueirêdo.

came.3@botmail.com

Rua Gutiúba, 35, Cabanga, Recife, Pernam-

buco, Brasil.

CEP: 50090-360.

DOI

$10.12820 /$ rbafs. $25 \mathrm{e} 0181$

\begin{abstract}
The aim of this study was to describe the knowledge and attitude of professionals in the Academia da Cidade Program (ACP) in relation to social control. A cross-sectional, descriptive study with a quantitative and qualitative approach was carried out, using a self-administered questionnaire. The data were tabulated using the EpiData Entry v program. 3.1. For the analysis of the quantitative data, SPSS software version 10.0 was used, results were presented in relative and absolute frequencies. For qualitative analysis, the Content Analysis proposed by Bardin was used. 104 professionals participated, who understand social control with "Participation of users, workers and managers in the planning, formulation, evaluation and inspection of health actions, plans, projects and programs". The majority (61.5\%) participated in health conferences, considered this participation as very important $(62.5 \%)$. Moreover, the great majority $(81.7 \%)$ encouraged users to participate in social control spaces, as well as, valued and reflected $(93.3 \%)$ on the demands indicated by them. However, more than $90.0 \%$ did not participate in health councils and territorial meetings. As a result, it was found that the majority of ACP professionals know social control according to the theoretical framework of the Unified Health System. As for the attitude, they participated in conferences, encouraged users to be participative and valued the claims brought by their routine work in the Program. However, they did not participate in the health councils and the social control spaces within their territory. It is suggested that these findings guide educational and training actions at the municipal and state levels.
\end{abstract}

Keywords: Social control; Social participation; Health promotion; Motor activity; Primary health care.

\section{RESUMO}

O objetivo deste estudo foi descrever o conhecimento e a atitude dos profissionais do Programa Academia da Cidade (PAC) com relação ao controle social. Foi realizado um estudo transversal, descritivo e de abordagem quantitativa e qualitativa, utilizando um questionário autoaplicado. A tabulação dos dados foi efetuada no programa EpiData Entry v. 3.1. Para análise dos dados quantitativos foi utilizado software SPSS versão 10.0, resultados apresentados em frequências relativas e absolutas. Para análise qualitativa, utilizou-se a Análise de Conteúdo proposta por Bardin. Participaram 104 profissionais, que compreendem o controle social com "Participação dos usuários, trabalhadores e gestores no planejamento, formulação, avaliação e fiscalização das açôes, planos, projetos e programas na saúde”. A maioria (61,5\%) participou de conferência de saúde, consideraram essa participação como muito importante (62,5\%). Estimulavam (81,7\%) os usuários a participarem de espaços de controle social, bem como, valorizavam e refletiam (93,3\%) sobre as demandas indicadas por eles. No entanto, mais de 90,0\% não participavam de conselhos de saúde e de reuniöes territoriais. Com isso, verificou-se que a maioria dos profissionais do PAC conhecem o controle social de acordo com o referencial teórico do Sistema Único de Saúde. Quanto a atitude, participaram de conferência, incentivavam os usuários a serem participativos e valorizam as reivindicaçôes por eles trazidos na rotina do trabalho no Programa. Contudo, não participavam dos conselhos de saúde e dos espaços de controle social dentro do território de atuação. Sugere-se que os achados desse estudo sejam alvo de açôes educativas e formativas no âmbito municipal e estadual.

Palavras-chave: Controle social; Participação social; Promoção da saúde; Atividade motora; Atenção primária a saúde. as a municipal Health Promotion strategy through the Regulatory Ordinance no. 122 of September 28, 2006. It was further strengthened when the National Health Promotion Policy was published in the Unified Health System (SUS), in $2006^{1-3}$. 
The following actions are among the ones developed by the ACP: promotion of physical activity, assessment of physical fitness, health education, in addition to citizen's encouragement through guidance and support for users and professionals to participate in conferences and health councils. These last two activities are legitimate forms of social participation in health management and are foreseen in the 1988 Federal Constitution ${ }^{4}$, in its article 198, which deals with SUS guidelines: decentralization, integrity and community participation ${ }^{5-6}$.

According to Oliveira et al. ${ }^{7}$ when health councils and conferences are employed, they contribute to the decentralization and democratization of social policies in Brazil. Decentralization starts from the perspective that "the closer the decision is made, the greater the chance of getting it right", and with regards to social control "the greater the involvement of society in the construction and supervision of the SUS, the greater the chances of success".

The exercise of social control is based on the democratization of knowledge and encouragement on the organization of society for the effective exercise of direct democracy in the management of the SUS ${ }^{8}$. According to Boaventura de Sousa Santos ${ }^{9}$, social control, is one of the instruments to radicalize democracy. The radicalization of democracy can be done in two ways, the first by deepening the sharing of authority and the second, extending it to an increasing number of domains of social life, transforming it into a potentially regulating principle of all social relations.

According to Law 8,142 / 1990, which provides for community participation in the management of SUS, councils are permanent collegiate bodies with a deliberative character for the formulation and monitoring of public health policies ${ }^{5}$. In these formal spaces of social control, all subjects involved in the SUS have a role in its implementation: professionals, providers, managers and, especially, users who are at the tip of the system and who follow the daily public policy ${ }^{8}$.

Social participation or social control seeks to guarantee the involvement of the population (users, workers and managers) on an equal basis (50\% of users, $25 \%$ of workers and $25 \%$ of managers) in the entire public policy process, starting at the proposition, until the inspection and evaluation of this process, encompassing planning, formulations (plans, projects and programs), monitoring their execution, and the definition of allocation of resources, so that interests of the collective can be met ${ }^{5,10}$.

Important advances in Brazilian public health were possible due to the holding of national health conferences, the effective participation of Physical Education in these spaces can expand knowledge in this area, as well as contribute to greater compression regarding the reality and health needs of the population, thus increasingly aligning the service offerings with the demands of the population, and also contribute to research in the area so that they have a greater relationship with these demands ${ }^{11}$. To this end, investments should be made in actions in health services and social facilities in communities that contribute to expanding the participation of health professionals and the population in spaces of social control.

The ACP is also a result of social control, it was expanded and qualified in the municipality based on the social participation of professionals and users in health conferences. With the engagement of all those involved, the agenda for implementing the ACP has always been present in the municipal health plans. As an example, some results of the performance of social control in the ACP were the expansion of the number of centers, and the holding of a public contest for hiring the professionals ${ }^{12,13}$.

However, it is known that movements to mobilize the population to be active in social control cannot be punctual nor temporary, on the contrary, it is essential to carry out permanent health education on the subject and the creation and maintenance of spaces and actions within the ACP to encourage and achieve this participation. Thus, the aim of this study was to describe the knowledge and attitude of ACP professionals in relation to social control.

\section{Method}

A cross-sectional descriptive study with a quantitative approach was conducted, originated from a research project entitled "Inclusion of the Academia da Cidade Program in Primary Health Care in the City of Recife: Perception of Academia da Cidade Program and Primary Health Care Professionals" which was prepared by ACP's professionals to conclude the post-graduation lato sensu Physical Activity and Public Health, promoted by the Municipal Secretariat of Recife in partnership with the University of Pernambuco.

The study site was the 41 hubs of the Academia da Cidade Program in the city of Recife, distributed in eight health districts. The study population consisted 
of 118 Physical Education professionals, out of a total of 182, but of these 64 were excluded from the study because they did not meet the inclusion criteria. Professionals who were away from the medical certificate, vacation, maternity leave, award or study, who worked at the Ermírio de Moraes Medical Center and the Experimental Pole of UPE, in addition to the professionals who were part of the program coordination and those who were part of the research team of this study, were excluded. Thus, of 118 eligible professionals, two refused and 12 were considered losses, totaling the final sample with 104 ACP professionals.

The data collection instrument was a self-administered questionnaire to the professionals at the $\mathrm{ACP}$ centers. This was prepared with objective questions, based on more recent studies on the theme and in accordance with the reality of the Program. To reduce the limitations of the questionnaire, a pilot test was applied before its definitive use. The questionnaire was organized into ten sessions, namely: (1) sociodemographic and professional, (2) role in the ACP, (3) extra hub activities, (4) physical structure, equipment, materials, cleaning and safety, (5) district meeting, (6) training meeting, (7) level of satisfaction, (8) absenteeism, (9) social control and (10) articulation with primary health care.

The variables analyzed in this study were sociodemographic and professional in order to (1) characterize the population and, the section on social control (9), to identify the knowledge and attitude of professionals. In the section referring to sociodemographic and professional information, the following variables were analyzed: sex, age, schooling, graduation degree, undergraduate public health discipline, internship in public health, training to work in the ACP. In the section on social control, the variables regarding knowledge, was the knowledge about social control (discursive question) and how much attitude were as follows: participation in health conference, participation in health council, thematic of permanent education meetings and participation in territorial meetings.

For data collection, undergraduate students from the University of Pernambuco were duly trained to apply the questionnaire. Data collection took place through pre-scheduled visits, primarily at district meetings, then at permanent education meetings and finally at the hubs. It was carried out from July 2015 to August 2015.

The data compilation procedure was performed using the EpiData Entry program (version 3.1). For the analysis of quantitative data, SPSS version 10.0 software was used, with results shown in relative and absolute frequencies. For the open questions, content analysis was performed according to Bardin's propos$\mathrm{a}{ }^{14}$, carrying out the following steps: floating reading, data ordering, rereading, and coding the material.

The research project to which this study is linked was approved by the Ethics Committee in Research with Human Beings at the University of Pernambuco through opinion No. 1,138,920. The subjects' participation was voluntary and by signing the Informed Consent Form.

\section{Results}

The study included 104 ACP professionals, all of whom have a degree in Physical Education, most of them female (61.5\%), aged between 30 and 39 (76.9\%). The majority (85.6\%) did not take a Public Health course at the undergraduate school and did not have an internship in the Public Health area (71.2\%). When asked if they had any training to work in the ACP, 73.1\% replied negatively (Table 1 ).

As for the professionals' knowledge about social control, the words most cited in the conceptualization were the following: "population", "action", "society", "bealth" and "SUS". Most responded that they understood the social control as "Participation of users, workers and managers in the planning, formulation, evaluation and inspection of health actions, plans, projects and programs" and "User participation in the planning, formulation, evaluation and inspection of health actions, plans, projects and programs". Few ACP professionals did not know how to respond or responded as follows: "Events produced for popular participation", "Show data", "Conduct studies to impact social programs" and "Guide society about some aspects".

When asked if they had already participated in any health conference, from 2002 to 2014, as a representative of the "professional" category, $61.5 \%$ responded positively, however $29.8 \%$ participated only in one conference. Unlike participating in a health conference, $91.3 \%$ of professionals stated that they had never participated in health councils during the period under investigation.

When asked about the importance that professionals recognize in their participation and that of ACP users in health conferences, $62.5 \%$ stated that they believe it is very important. When asked whether, in professional practice, they encouraged the participation 
Table 1 - Description of the socio-demographic and training profile of ACP professionals, Recife, 2015 ( $n=104$ )

\begin{tabular}{|c|c|c|}
\hline Variables & $\mathrm{n}$ & $\%$ \\
\hline \multicolumn{3}{|l|}{ Sex } \\
\hline Female & 64 & 61.5 \\
\hline Male & 40 & 38.5 \\
\hline \multicolumn{3}{|l|}{ Age } \\
\hline 20 to 29 & 4 & 3.8 \\
\hline 30 to 39 & 80 & 76.9 \\
\hline 40 to 49 & 18 & 17.3 \\
\hline 50 to 59 & 2 & 1.9 \\
\hline \multicolumn{3}{|l|}{ Schooling } \\
\hline Under Graduation & 27 & 26.0 \\
\hline Specialization & 70 & 67.3 \\
\hline Internship & 1 & 1.0 \\
\hline Master's & 6 & 5.8 \\
\hline \multicolumn{3}{|l|}{ Degree obtained } \\
\hline Full Teaching Degree & 99 & 95.2 \\
\hline Teaching Degree & 2 & 1.9 \\
\hline B.A & 1 & 1.9 \\
\hline Teaching Degree and B.A & 1 & 1.0 \\
\hline Not answered & 1 & 1.0 \\
\hline \multicolumn{3}{|c|}{ Public Health Subject at the Undergraduation } \\
\hline Yes & 15 & 14.4 \\
\hline No & 89 & 85.6 \\
\hline \multicolumn{3}{|l|}{ Internship in Public Health } \\
\hline Yes & 28 & 26.9 \\
\hline No & 74 & 71.2 \\
\hline Not answered & 2 & 1.9 \\
\hline \multicolumn{3}{|l|}{ Training to work in ACP } \\
\hline Yes & 28 & 26.9 \\
\hline No & 76 & 73.1 \\
\hline
\end{tabular}

of ACP users in social control spaces, $81.7 \%$ answered positively. And the majority (92.3\%) of the professionals stated that the theme of social control is addressed and / or encouraged in the permanent education meetings of the Program.

Regarding the attitude of professionals relating to listening, reflecting, valuing the demands and requirements of ACP users, 93.3\% stated that they listen, reflect, value the demands brought by the users. On the other hand, a large part of these professionals (92.3\%) does not participate in any territorial meetings (council meeting of residents, associations of residents, meeting of users in health units). Those who participate do so with a frequency of once a month.

\section{Discussion}

From the results found, it can be seen that the theme of social control was not strange to most ACP professionals, even when the initial training profile showed the absence of relatedness with SUS. Professionals
Table 2 - Description of the participation and development of social control by ACP professionals. Recife, 2015 ( $n=104)$

\begin{tabular}{|c|c|c|}
\hline Variables & $\mathrm{n}$ & $\%$ \\
\hline \multicolumn{3}{|c|}{ Participation in health conference between 2002 and 2014} \\
\hline No & 40 & 38.5 \\
\hline Yes & 64 & 61.5 \\
\hline \multicolumn{3}{|c|}{ Number of Conferences attended } \\
\hline 1 Conference & 31 & 29.8 \\
\hline 2 Conferences & 14 & 13.5 \\
\hline 3 Conferences & 5 & 4.8 \\
\hline 4 Conferences & 3 & 2.9 \\
\hline 6 Conferences & 1 & 1.0 \\
\hline Not applicable & 40 & 38.5 \\
\hline Not answered & 10 & 9.6 \\
\hline \multicolumn{3}{|c|}{ Participation in Health Councils between 2002 and 2014} \\
\hline No & 95 & 91.3 \\
\hline Yes & 9 & 8.7 \\
\hline \multicolumn{3}{|c|}{ Amount of participation in Health Council } \\
\hline 1 counsel & 6 & 5.8 \\
\hline Not applicable & 95 & 91.3 \\
\hline Not answered & 3 & 2.9 \\
\hline \multicolumn{3}{|c|}{$\begin{array}{l}\text { Importance of the participation of ACP users and } \\
\text { professionals in health conferences }\end{array}$} \\
\hline Somewhat importante & 4 & 3.8 \\
\hline Important & 34 & 32.7 \\
\hline Very importante & 65 & 62.5 \\
\hline Not answered & 1 & 1.0 \\
\hline \multicolumn{3}{|c|}{$\begin{array}{l}\text { Professionals who encourage ACP users to } \\
\text { participate in social control }\end{array}$} \\
\hline No & 15 & 14.4 \\
\hline Yes & 85 & 81.7 \\
\hline Not answered & 4 & 3.8 \\
\hline \multicolumn{3}{|c|}{$\begin{array}{l}\text { Incentives to the social control of professionals and } \\
\text { users of ACP in permanent education meetings }\end{array}$} \\
\hline No & 7 & 6.7 \\
\hline Yes & 96 & 92.3 \\
\hline Not answered & 1 & 1.0 \\
\hline \multicolumn{3}{|c|}{$\begin{array}{l}\text { Professional listens / reflects / values / forwards } \\
\text { the demands of ACP users in their professional } \\
\text { performance }\end{array}$} \\
\hline No & 6 & 5.8 \\
\hline Yes & 97 & 93.3 \\
\hline Not answered & 1 & 1.0 \\
\hline \multicolumn{3}{|c|}{ Participation of the ACP professional in territorial meetings } \\
\hline No & 96 & 92.3 \\
\hline Yes & 6 & 5.8 \\
\hline Not answered & 2 & 1.9 \\
\hline \multicolumn{3}{|c|}{$\begin{array}{l}\text { Frequency of participation of PAC professionals in } \\
\text { territorial meetings }\end{array}$} \\
\hline Once a month & 3 & 2.9 \\
\hline Every 3 months & 1 & 1.0 \\
\hline Every 6 months & 1 & 1.0 \\
\hline Not applicable & 96 & 92.3 \\
\hline Not answered & 3 & 2.9 \\
\hline
\end{tabular}


know the concept in a broader way beyond inspection, but some related only to user's participation, excluding professionals and managers. The permanent education meetings represent a space to learn and debate about social control. In general, the professionals had at least one experience in a health conference, considered this participation very important and encouraged users to be present and active in social control spaces. However, they did not participate in spaces such as health councils and territorial meetings.

Most ACP professionals understand the concept of social control in a coherent way, indicating that the society participates in the management of the health system, and so, are aligned with the theoretical framework of SUS ${ }^{4-6}$. This is a relevant result, given the importance of social control in the construction of SUS, as it is fundamental for its implementation and consolidation ${ }^{7,8}$.

Although only few professionals said they did not know how to answer and, few others have distanced themselves from an adequate understanding of social control, this finding should be observed. In this way, it is suggested that ACP should maintain and improve permanent education actions on that theme, as well as that the graduation schools should include this content in their initial training. Some studies ${ }^{15,16}$ point that this knowledge about social control must be stimulated not only in the training of future SUS professionals, and in the classroom and curricular internships, but also in their professional performance, through permanent education. In this way, such professionals will be able to take to communities the incentive to occupy such spaces in a qualified and critical way, and fight for an increasingly better public health system.

About participation in social control spaces, such as health conferences, Loch ${ }^{11}$ states that it is of great importance, however, this participation needs to be more effective. As the findings in this study show, ACP professionals have some participation in conferences, but most of them have participated once only. As for the low participation in health councils and meetings in the territory in which they operate, some authors ${ }^{7,17}$ found the lack of time, due to the accumulation of labor activities, as a justification. However, they argue that attention must be paid so that participation in the councils is not weakened, limited to the prerogative of inspection, and emptied of the fundamental objectives of social control spaces.

Therefore, when it comes to social control, it is important, in addition to conceptually knowing and par- ticipating in conferences, to deepen the possibilities of action that the legislation allows, so that the contributions are really effective. It is necessary to know the territory, the functioning of the network, the place where the health department is inserted, the way the city is administered and its hierarchy. Users and professionals must understand the functioning of conferences and councils and play a critical and active role in these locations ${ }^{18,19}$.

The Physical Education professional can and should be an articulator of the political process, stimulating and guiding active and permanent social participation in health promotion spaces such as $\mathrm{ACP}^{18}$.

It is necessary not only to encourage users to participate in conferences and health councils, but also to start this participation in the work routine within the groups of bodily practices, to decide together which and how activities will be carried out, giving directions together with the users ${ }^{18,19}$.

It is necessary to prepare strategies together with the local population so that their own solutions are formulated and suggested, in the approach to community health management. According to Shimizu et al. ${ }^{20}$ when this work is done through health workers, it is a very important anti-hegemonic effort, so that the management does not determine the public health policies according to their own interests. Occupying and demarcating this speech territory is fundamental for the demands of the workers and the communities to be implemented as health policy.

It is important to indicate that the limitations of this study are recognized, given its cross-sectional characteristic that does not allow to make causatous relationships, so it is suggested that similar studies are conducted that can deepen the discussions raised in this manuscript. However, it was possible to present even descriptively the approximations of cap professionals with social control, either from their knowledge and from their attitudes. Its potential ity was to address the actions that these professionals develop in their work routine that are aligned with the conception of social control in the SUS. And with this, to realize how much progress has already been made in the inclusion and maintenance of mobilization and social participation actions in the ACP, as to what still needs to be made to make the actions systematic and increasingly articulated with the populations of the territories of these professionals' activities.

Finally, it is concluded that the majority of ACP's professionals understand social control according to 
the theoretical framework of SUS. From an attitudinal point of view, they participated in health conferences, encouraged users to be participative in social control spaces, and valued the claims they bring within their work routine in the Program. However, they did not participate in health councils and social control spaces within their operation territory.

It is recommended that the notes indicated in this study can be included in ACP's permanent education meetings, as well as being the target of other educational and training actions at the municipal and state levels. As a result, they will be more likely to be discussed, reviewed and implemented in a way that will contribute to expanding the social participation of professionals, users and managers of the Program in the perspective of strengthening the social control of SUS.

\section{Conflict of interest}

The authors declare no conflict of interest.

\section{Authors' contributions}

Figueirêdo CAM, Silva BCR \& Albuquerque AEMT participated in the initial study design, data collection and analysis, writing and critical review of the text. Brainer MG, was responsible for the literature search, data collection and critical text review. Soares SETOM, contributed to the literature search, data collection and critical text review. Lemos EC, contributed to the initial study design, data analysis, writing and critical review of the text. All authors approved the final version.

\section{Acknowledgment}

The authors would like to thank the professionals of ACP, the City of Recife, ACP and the University of Pernambuco.

\section{References}

1. Lemos EC, Gouveia GC, Luna CF. Programa Academia da Cidade: a experiência do Recife. In: Gurgel IGD, Medeiros KR, Aragão AV, Santana RM (eds). Gestão em Saúde Pública: Contribuições para a Política. Recife: Editora UFPE; 2014.p. 139-53.

2. Brasil. Brasil. Ministério da Saúde. Secretaria de Vigilância em Saúde. Política nacional de promoção da saúde / Ministério da Saúde, Secretaria de Atenção à Saúde. Brasília: Ministério da Saúde, 2006. [citado em 2020 abr 15]. Disponível em: http://bvsms.saude.gov.br/bvs/publicacoes/ politica_promocao_saude.pdf.

3. Brasil. Ministério da Saúde. Secretaria de Vigilância em Saúde. Secretaria de Atenção à Saúde. Política Nacional de Promoção da Saúde: PNPS: Anexo I da Portaria de Consolidação no 2, de 28 de setembro de 2017, que consolida as normas sobre as políticas nacionais de saúde do SUS/ Ministério da Saúde, Secretaria de Vigilância em Saúde, Secretaria de Atenção à Saúde. Brasília: Ministério da Saúde, 2018. [citado em 2020 abr 15]. Disponível em: https://bvsms.saude.gov.br/bvs/ publicacoes/politica_nacional_promocao_saude.pdf.
4. Brasil. Constituição da República Federativa do Brasil. Brasília, DF: Senado Federal, 1988. [citado em 2020 abr 12]. Disponível em: https://www.bmn.com.br/plan-leg/ma/fed/ cf/cf-88.pdf.

5. Brasil. Casa Civil/Presidência da República. Lei n. ${ }^{\circ} 8.142,28$ de dezembro de 1990. Diário Oficial da República Federativa do Brasil. Brasília, 31 dez 1990. Dispõe sobre a participação da comunidade na gestão do Sistema Único de Saúde - SUS e sobre as transferências intergovernamentais de recursos financeiros na área da saúde e dá outras providências. [citado em 2020 abr 12]. Disponível em: http://www.planalto.gov.br/ ccivil_03/leis/L8142.htm.

6. Brasil. Conselho Nacional de Saúde, Ministério da Saúde. Para entender o controle social na saúde. Brasília: Editora MS; 2014. [citado em 2020 abr 10]. Disponível em: https:// conselho.saude.gov.br/biblioteca/livros/Manual_Para_ Entender_Controle_Social.pdf.

7. Oliveira AMC, Ianni AMZ, Dallari SG. Controle social no SUS: discurso, ação e reação. Ciênc Saú Colet. 2013;18(8):2338-9.

8. Centro de Educação e Assessoramento Popular. Conselho Nacional de Saúde. O SUS e a efetivação do direito humano à saúde. Organização Pan Americana da Saúde. Passo Fundo: Editora do IFIBE; 2017. [citado em 2020 abr 10]. Disponível em: https://rest.formacontrolesocial.org.br/materials/ cartilha-ceap.pdf

9. Santos BS. Quinze teses para aprofundar a democracia. Brasília: UnB, 2008.

10. Souza MF, Souza Junior FV. Controle social: um estudo acerca do conselho municipal de saúde de Apodi. Rev Fides. 2019;10(1):214-28.

11. Loch MR. A educação física e a $15^{a}$ conferência nacional de saúde. Rev Bras Ativ Fís Saúde. 2015;20(1):1-2.

12. Prefeitura da Cidade do Recife. Plano Municipal de Saúde 2006-2009. Recife saudável: inclusão social e qualidade no SUS. Recife, 2005. [citado em 2020 abr 9]. Disponível em: http://www.recife.pe.gov.br/noticias/arquivos/227.pdf.

13. Prefeitura da cidade do Recife, Governo Municipal, Secretaria de Saúde do Recife, Secretaria Executiva de Coordenação Geral, Diretoria Executiva de Planejamento, Orçamento e Gestão da Informação. Plano Municipal de Saúde 2018 2021. Recife, $1^{\text {a }}$. Ed, 2018. [citado em 2020 abr 9]. Disponível em: http://www2.recife.pe.gov.br/sites/default/files/plano_ municipal_de_saude_2018_2021_vf.pdf.

14. Bardin L. Análise de Conteúdo. 3a ed. Lisboa: Edições 70, 2011.

15. Costa AM; Vieira NA. Participação e controle social em saúde. Fundação Oswaldo Cruz. A saúde no Brasil em 2030. Rio de Janeiro: 2013;3:237-271. [citado em $2020 \mathrm{abr}$ 26]. Disponível em: http://books.scielo.org/id/98kjw/pdf/ noronha-9788581100173-08.pdf.

16. Alencar HHR. Educação permanente no âmbito do controle social no SUS: a experiência de Porto Alegre - RS. Saúde Soc. 2012;21 (1.1):223-233.

17. Shimizu HE, Moura LM. The social representations of social control in health: the advances and effect of institutionalized social participation. Saúde Soc. 2015;24(4):1180-92.

18. Oliveira $\mathrm{BN}$, Wachs $\mathrm{F}$. Educação física, atenção primária à saúde e organização do trabalho com apoio matricial. Rev Bras Ciênc Esporte. 2019;41(2):183-9.

19. Carvalho AC. Elaboração participativa de estratégias de facilitação para a realização de atividade física por usuários de uma unidade básica de saúde [dissertação de mestrado]. Rio de Janeiro: Estácio; 2019. 
20. Shimizu HE, Pereira MF, Cardoso AJC, Bermudez XPCD.

Social representations of municipal counselors regarding social control in health in the Brazilian Unified Health System (SUS). Ciênc Saúde Colet. 2013;18(8):2275-84.

Received: 30/06/2020 Approved: 15/02/2021

\section{Quote this article as:}

Figueirêdo CAM, Silva BCR, Albuquerque AEMT, Brainer MG, Soares SETOM, Lemos EC. Social control: knowledge and attitude of professionals in the Academia da Cidade Program. Rev Bras Ativ Fís Saúde. 2020;25:e0181. DOI: 10.12820/rbafs.25e0181 